\title{
The Influence of Air Pollution on Corticolous Lichens near the Strathcona Industrial Area, Alberta
}

\author{
M. Elsinger ${ }^{1}$, E. Burrell ${ }^{1}$, N. DeBruyn ${ }^{1}$, K. TANASichuk ${ }^{1}$, and K. Timoney ${ }^{2}$ \\ ${ }^{1}$ Department of Biological Sciences, University of Alberta, Edmonton, Alberta T6G 2E1 Canada \\ ${ }^{2}$ Treeline Ecological Research, 21551 Township Road 520, Sherwood Park, Alberta T8E 1E3 Canada; email: ktimoney@ \\ compusmart.ab.ca; corresponding author
}

Elsinger, M., E. Burrell, N. deBruyn, K. Tanasichuk, and K. Timoney. 2007. The influence of air pollution on corticolous lichens near the Strathcona Industrial Area, Alberta. Canadian Field-Naturalist 121(1): 17-23.

Lichens that grow on the bark of mature trees were studied at 35 sites along an air pollution gradient east of Edmonton, Alberta. Data on species composition, richness, and cover were recorded in October 1999 in a matrix of sites that extends from a known source of pollutants (the Strathcona Industrial Area) east across Strathcona County. Air pollution is affecting the corticolous lichen community. Lichen species richness and total cover increased with distance from the pollution source. Species richness in areas distant from pollution was roughly twice that in areas near the Strathcona Industrial Area. Xanthoria fallax and Phaeophyscia orbicularis were the most pollution tolerant lichens. Xanthoria hasseana, Ochrolechia arborea, Physcia adscendens, Parmelia sulcata, and Melanelia albertana were rare or absent near the pollution source and common in more distant areas. Most of the 15 species assessed were sensitive to air quality to some degree. Some lichens near the refineries and in Sherwood Park showed abnormal coloration and poor thallus integrity indicative of stress. We discuss implications for human health.

Key Words: corticolous lichens, air pollution, health, refineries, vehicle emissions, Alberta.

Lichens are well-known indicators of air quality. While most lichen biomonitoring studies have been conducted in Europe and the United States, there is a growing body of such studies in Canada. In western Canada, 49 lichen species have been used to study general air pollution, while 39,23 , and 18 species have been used to monitor sulphur dioxide, photochemicals, and fluoride, respectively (Thormann 2006). Lichens have proven useful to characterize the concentrations and deposition patterns of air pollutants over large areas, particularly for metals, sulphur, and nitrogen compounds (Enns 2001*).

The fungal and algal partners of the lichen symbiosis live in a delicate balance. Any pollutant that affects the well-being of either partner affects the lichen as a whole (Brodo et al. 2001). Sensitivity to air pollution is related to several features of lichens. They obtain nutrients only from air and precipitation; they accumulate compounds in their thalli and have inefficient mechanisms of excluding or eliminating wastes, they have no protective epidermis or cuticle, and they are quick to show symptoms of stress (Case 1981*; USGS 2005*).

The concentration and constituents of air pollution vary in time and space. In Alberta, there are several important constituents and sources of air pollution (Alberta Environment 1996*; Alberta Health and Wellness 2003). Sulphur dioxide ( $\left.\mathrm{SO}_{2}\right)$ is released from natural gas processing plants, oil sands facilities, power plants, gas flaring, oil refineries, pulp and paper mills, and fertilizer plants. In Alberta, $42 \%$ of $\mathrm{SO}_{2}$ is emitted from natural gas processing plants (Myrick and Hunt 1998*). Hydrogen sulphide is released from fugitive emissions (leakages) at petroleum refineries, tank farms for unrefined petroleum products, natural gas and petrochemical plants, oil sands plants, sewage treatment plants, kraft pulp and paper plants, and animal feedlots. Natural sources include sulphur hot springs and some wetlands and lakes.

Nitrous oxides are produced from high temperature combustion of natural gas, coal, oil, and gasoline. Nitrogen dioxide $\left(\mathrm{NO}_{2}\right)$ is a pungent toxin. Ozone near ground level comes from reaction of nitrous oxides and volatile organic compounds in the presence of sunlight and from transport of upper atmosphere ozone down to ground level. Ozone levels are generally lower in urban and polluted areas as ozone is destroyed by nitric oxide (NO). Hydrocarbons come from a variety of industrial and natural sources. The most abundant hydrocarbon in the Earth's atmosphere is methane, a potent greenhouse gas. Reactive hydrocarbons such as alkenes, alkynes, and aromatics are toxic to humans and other animals and vegetation. They react with nitrous oxides in the presence of sunlight to form ozone.

Particulates come from a variety of sources (typically combustion) and can act as carriers for biologically active metals and combustion products. Particulate monitoring is based on the mass of particles filtered per $\mathrm{m}^{3}$ of air; $\mathrm{PM}_{10}$ and $\mathrm{PM}_{2.5}$ refer to particles $<10 \mu \mathrm{m}$ and $<2.5 \mu \mathrm{m}$ respectively. In Alberta, the ratio of $\mathrm{PM}_{25}$ : $\mathrm{PM}_{10}$ in recent years has ranged from 0.52 to 0.59 (Pollution Watch 2006*).

Alberta is the largest emitter of air pollutants in Canada, with a 2005 release of 1.339 billion $\mathrm{kg}, 28.4 \%$ of the national total, an increase of $62 \%$ over its 2002 pollutant release (Pollution Watch 2006*). Among the criteria air contaminants that affect human and ecosys- 
tem health, Alberta released 412.8 million $\mathrm{kg}$ of sulphur dioxide and 403.9 million $\mathrm{kg}$ of oxides of nitrogen in 2005 (Pollution Watch 2006*).

Lichens can be harmed by a variety of air pollutants, including sulphur dioxide, sulfuric and nitric acids, ozone, hydrocarbons, fluorides, and metals such as copper, lead, and zinc (Brodo et al. 2001). Sulphur dioxide impacts on lichens have been noted in Europe since the early $19^{\text {th }}$ century (Simonson 1996*) and can cause decreased species richness, diversity and vitality (Case 1981*). Pollution-tolerant lichens may exhibit increased cover in polluted areas because of decreased competition with more sensitive species, such as Melanelia albertana (Muir and McCune 1988; Forest Health Highlights $\left.1994^{*}\right)$. Comparative study of the lichens in an urban or industrial area with those distant from pollution can provide a good indicator of air quality.

Our objective was to determine if there are spatially detectable effects on the lichen communities of mature tree bark within and downwind of pollution sources. We focused on the corticolous lichen species that grow on Balsam Poplar (Populus balsamifera) and Trembling Aspen (Populus tremuloides) trunks.

\section{Study Area}

The study area and the Strathcona Industrial Area ("Refinery Row", Figure 1) are located east of Edmonton, Alberta. Refinery Row contains a large group of refineries and other industrial plants and is downwind of Edmonton. Sherwood Park, Fort Saskatchewan, and rural Strathcona County are downwind of Refinery Row. Major sources of air pollution from Refinery Row are industrial plants and vehicle emissions (Alberta Environment 1997*).

\section{Methods}

Study sites spanned an area roughly $28 \mathrm{~km}$ east-west and $14 \mathrm{~km}$ north-south downwind (east) of the primary pollution source in the Strathcona Industrial Area. Study sites were located in naturally forested areas both public and private. Two crews of two people each sampled a total 35 sites in mid-October 1999. Only mature trees with diameters $>20 \mathrm{~cm}$ at breast height were sampled. Balsam Poplar was the preferred tree as its rough bark afforded abundant microsites for lichens. Aspen were also sampled. Prior to sampling, we learned to recognize a subset of the lichen flora. We focused on 15 taxa readily identifiable in the field.

At each site, we chose the four trees with the highest lichen cover. These trees had rough or fissured bark and were usually the largest and oldest trees present. Our data indicate average maximum cover rather than average cover. For each tree, we noted the tree species and diameter at breast height and determined the percent cover of each lichen species growing on the bark in the zone $0.5-1.5 \mathrm{~m}$ above the ground. Locations were recorded with a GPS unit. Lichen names follow Brodo et al. (2001).

For each site, we determined mean percent cover for each species and all combined species and the total number of species. Lichen cover and location data were analysed statistically. While air pollutants originate from the entire industrial area, and from Edmonton in general, we defined a single pollution source point to quantify distance from source. That point was defined as the junction of Baseline Road and $34^{\text {th }}$ Street on the west side of Refinery Row. Distances from each site to the defined pollution source were determined in a geographic information system.

\section{Results}

Of the 15 taxa of corticolous lichens assessed, six tended to be common and dominant and nine uncommon and non-dominant (Tables 1, 2). Lichen species richness and cover increased with distance from the pollution source (Figure 2). Relationships with distance were strongest for species richness and for nondominant species cover (Table 3 ). Both richness and cover appeared to rise exponentially with distance. Species richness and total cover increased gradually from west to east over the first $15-20 \mathrm{~km}$ of the pollution gradient, then increased more rapidly (Figure 3). Minimum richness and cover were found in the northwestern sites. Richness and cover continued to rise over the gradient indicating that air quality influenced the lichen community across the entire area. Some lichens near the refineries and in Sherwood Park showed abnormal coloration (e.g., pale colors, or pinkish hues) and poor thallus integrity (partly disintegrated thalli) indicative of stress.

Of the six dominant species, all but one species (Phaeophyscia orbicularis) increased in cover with dis-

TABLE 1. Corticolous lichen species observed on mature Balsam Poplar and Trembling Aspen bark in the study.*

\begin{tabular}{l}
\hline Dominant Species \\
\hline Melanelia albertana \\
Ochrolechia arborea \\
Phaeophyscia orbicularis \\
Physcia adscendens \\
Xanthoria fallax \\
Xanthoria hasseana \\
\hline Non-dominant Species \\
\hline Arthonia patellulata \\
Bryoria spp. \\
Evernia mesomorpha \\
Flavopunctelia flaventior \\
Hypogymnia physodes \\
Parmelia sulcata \\
Parmeliopsis ambigua \\
Physcia aipolia \\
Usnea spp. \\
* non-dominant species occurred at $<5 \%$ cover at most sites
\end{tabular}



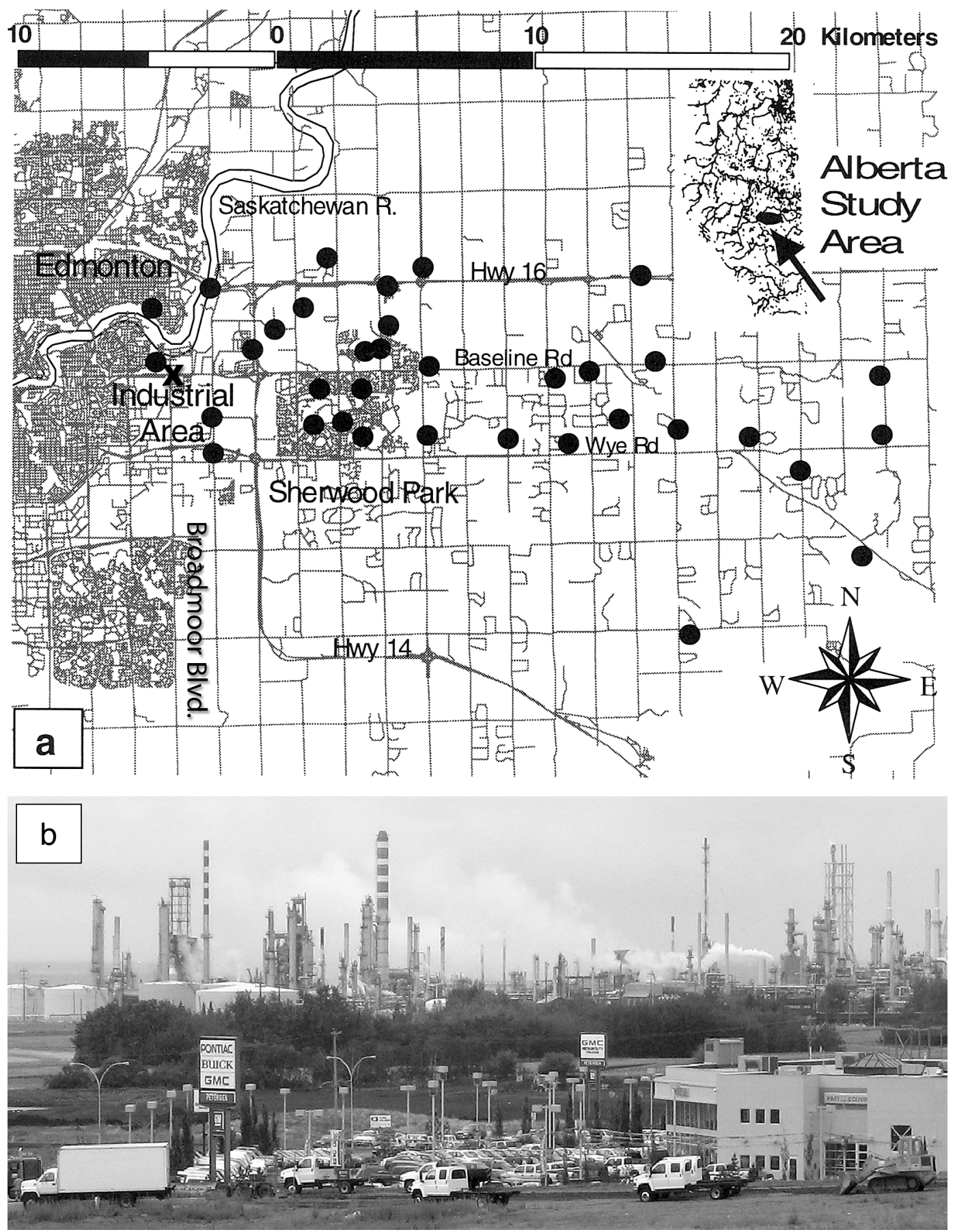

FigurE 1. (a) Location of the 35 study sites. The area marked with an X, at the corner of Baseline Road and $34^{\text {th }}$ Street (Edmonton), was the reference point for measurement of distances from the pollution sources. (b) Part of the Strathcona Industrial Area as seen from the corner of Baseline Road and Broadmoor Boulevard (west side of Sherwood Park, 9 June 2006). 
TABLE 2. Cover (\%) of six common, dominant lichen taxa, non-dominant species cover, total cover, species richness, distance from pollution source, and location (UTM, Alberta 10TM projection) for the 35 study sites.

\begin{tabular}{|c|c|c|c|c|c|c|c|c|c|c|c|c|}
\hline$\stackrel{0}{=}$ & 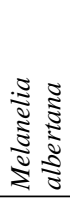 & 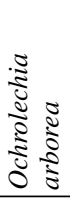 & 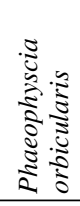 & 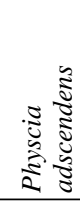 & 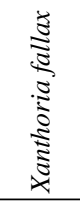 & 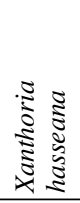 & 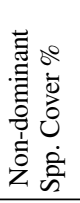 & $\begin{array}{l}0 \\
0 \\
0 \\
0 \\
0 \\
0 \\
0 \\
0 \\
0\end{array}$ & 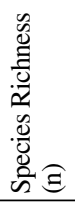 & 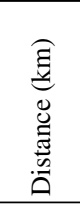 & 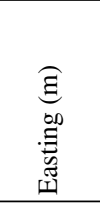 & 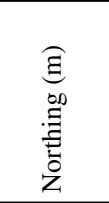 \\
\hline 1 & 1.53 & 1.28 & 9.50 & 10.50 & 9.25 & 24.25 & 4.80 & 61.1 & 10 & 22.20 & 626596 & 5921921 \\
\hline 2 & 1.53 & 1.75 & 6.25 & 27.50 & 15.50 & 20.78 & 3.57 & 76.9 & 12 & 27.64 & 634039 & 5929211 \\
\hline 3 & 1.25 & 5.53 & 6.25 & 30.75 & 13.00 & 9.28 & 5.55 & 71.6 & 11 & 27.51 & 633318 & 5924801 \\
\hline 4 & 9.50 & 6.25 & 5.50 & 18.75 & 9.25 & 6.25 & 5.13 & 60.6 & 10 & 27.43 & 633890 & 5931485 \\
\hline 5 & 1.03 & 0.33 & 10.50 & 23.75 & 27.00 & 5.80 & 1.13 & 69.5 & 11 & 24.60 & 630881 & 5927914 \\
\hline 6 & 1.03 & 1.05 & 17.00 & 9.50 & 8.50 & 6.25 & 1.01 & 44.3 & 9 & 22.63 & 628901 & 5929041 \\
\hline 7 & 4.03 & 5.53 & 7.75 & 9.50 & 13.50 & 2.55 & 2.55 & 45.4 & 9 & 18.64 & 624657 & 5935012 \\
\hline 8 & & 0.08 & 18.75 & 20.25 & 8.25 & 0.03 & 0.30 & 47.7 & 6 & 19.84 & 626128 & 5929300 \\
\hline 9 & & 0.28 & 18.25 & 15.00 & 2.75 & 0.30 & 0.57 & 37.2 & 8 & 17.51 & 623892 & 5929777 \\
\hline 10 & & 0.55 & 12.50 & 20.50 & 14.25 & 0.03 & 0.32 & 48.2 & 8 & 18.84 & 625218 & 5931805 \\
\hline 11 & 0.30 & 3.25 & 9.53 & 17.75 & 34.50 & 8.50 & 1.77 & 75.6 & 8 & 16.29 & 622666 & 5931547 \\
\hline 12 & 0.28 & 3.53 & 4.78 & 17.00 & 11.25 & 1.55 & 1.51 & 39.9 & 8 & 15.67 & 621909 & 5928835 \\
\hline 13 & & 0.55 & 5.28 & 18.28 & 10.50 & 0.03 & 0.52 & 35.2 & 6 & 14.94 & 621306 & 5931245 \\
\hline 14 & & 0.10 & 12.00 & 11.28 & 18.00 & 9.28 & 2.08 & 52.7 & 9 & 13.34 & 619624 & 5928966 \\
\hline 15 & & 0.10 & 13.75 & 13.25 & 9.50 & 1.25 & 0.58 & 38.4 & 7 & 10.21 & 616349 & 5929036 \\
\hline 16 & & 0.05 & 9.00 & 18.75 & 15.00 & 8.78 & 0.07 & 51.7 & 7 & 10.07 & 616497 & 5931618 \\
\hline 17 & & 0.08 & 6.25 & 15.03 & 17.50 & 5.03 & 0.77 & 44.7 & 6 & 10.59 & 616212 & 5935306 \\
\hline 18 & & 0.08 & 15.25 & 0.28 & 12.00 & 19.50 & & 47.1 & 5 & 9.07 & 614799 & 5934537 \\
\hline 19 & & & 30.00 & 0.08 & 4.75 & 0.55 & 1.02 & 36.4 & 5 & 8.12 & 614509 & 5932293 \\
\hline 20 & & 0.03 & 16.25 & 0.08 & 9.00 & & & 25.4 & 4 & 8.56 & 614809 & 5932530 \\
\hline 21 & 0.30 & 3.50 & 26.25 & 0.03 & 14.50 & 12.50 & 3.06 & 60.1 & 9 & 7.60 & 613904 & 5932179 \\
\hline 22 & 0.03 & 0.30 & 23.75 & 1.55 & 16.25 & 1.28 & 0.90 & 44.1 & 11 & 7.39 & 613821 & 5930774 \\
\hline 23 & & 0.08 & 38.00 & 4.00 & 11.75 & 6.00 & 1.82 & 61.7 & 7 & 7.77 & 613885 & 5929036 \\
\hline 24 & & & 10.00 & 18.78 & 1.03 & 0.03 & 0.08 & 29.9 & 6 & 3.28 & 608099 & 5928430 \\
\hline 25 & & 0.55 & 14.25 & 0.28 & 20.00 & 24.75 & 0.06 & 59.9 & 6 & 2.23 & 607989 & 5929730 \\
\hline 26 & & 0.05 & 14.50 & 1.55 & 15.00 & 0.53 & & 31.6 & 5 & 3.36 & 609589 & 5932220 \\
\hline 27 & & 0.03 & 23.75 & 6.75 & 3.53 & 0.03 & 0.35 & 34.4 & 7 & 3.56 & 607909 & 5934560 \\
\hline 28 & & 0.05 & 9.50 & 0.55 & 1.05 & & & 11.2 & 5 & 2.58 & 605709 & 5933730 \\
\hline 29 & & 0.55 & 14.28 & 1.03 & 3.50 & 0.05 & 0.10 & 19.5 & 8 & 0.77 & 605895 & 5931731 \\
\hline 30 & & & 10.50 & 0.08 & 16.25 & 3.78 & 0.05 & 30.7 & 5 & 5.87 & 612319 & 5930784 \\
\hline 31 & & 1.03 & 16.25 & 0.08 & 5.25 & 0.28 & 0.05 & 22.9 & 6 & 7.47 & 612501 & 5935549 \\
\hline 32 & & 3.03 & 26.25 & 6.30 & 4.78 & & 0.75 & 41.1 & 5 & 5.77 & 611558 & 5933780 \\
\hline 33 & & 0.53 & 35.00 & 1.55 & 21.25 & 0.03 & 0.05 & 58.4 & 7 & 4.43 & 610409 & 5933009 \\
\hline 34 & & & 31.25 & 3.00 & 26.52 & 0.75 & 0.28 & 61.8 & 5 & 6.86 & 613080 & 5929554 \\
\hline 35 & & 0.05 & 10.75 & 6.25 & 3.25 & 1.00 & 0.05 & 21.4 & 6 & 5.84 & 611981 & 5929452 \\
\hline
\end{tabular}

tance from the pollution source (Figure 4). Xanthoria fallax and Phaeophyscia orbicularis were the most hardy lichens, present in virtually all sample sites. Xanthoria hasseana and Ochrolechia arborea increased appreciably in cover with distance from the refineries. Physcia adscendens, Parmelia sulcata, and Melanelia albertana were rare or absent near the pollution source and common in more distant areas. Similarly, Flavopunctelia flaventior, Hypogymnia physodes, Usnea sp., Evernia mesomorpha, and Arthonia patellulata were rare to absent near the refineries. Most species were sensitive to air quality to some degree.

\section{Discussion}

Lichens are good bioindicators of air quality in the region. There were clear trends of decreasing cover and richness with increasing proximity to Refinery Row.
TABLE 3. Spearman rank correlations of distance from pollution source with lichen species richness and cover $(n=35$; all correlations were significant at $P<0.001$ ).

\begin{tabular}{lc}
\hline \hline Correlations (r) & Distance \\
\hline Species Richness & 0.61 \\
Total Cover & 0.57 \\
Dominant Species Cover & 0.51 \\
Non-dominant Species Cover & 0.67 \\
\hline \hline
\end{tabular}

The pattern of decreasing lichen cover and species richness with increasing levels of air pollution is consistent with that documented in large Canadian cities such as Winnipeg, Manitoba (Stringer and Stringer 1974), and Hamilton, Ontario (McCarthy and Vaughan 2004*).

The results support those of Muir and McCune (1988) and van Dobben and ter Braak (1999) who found that 

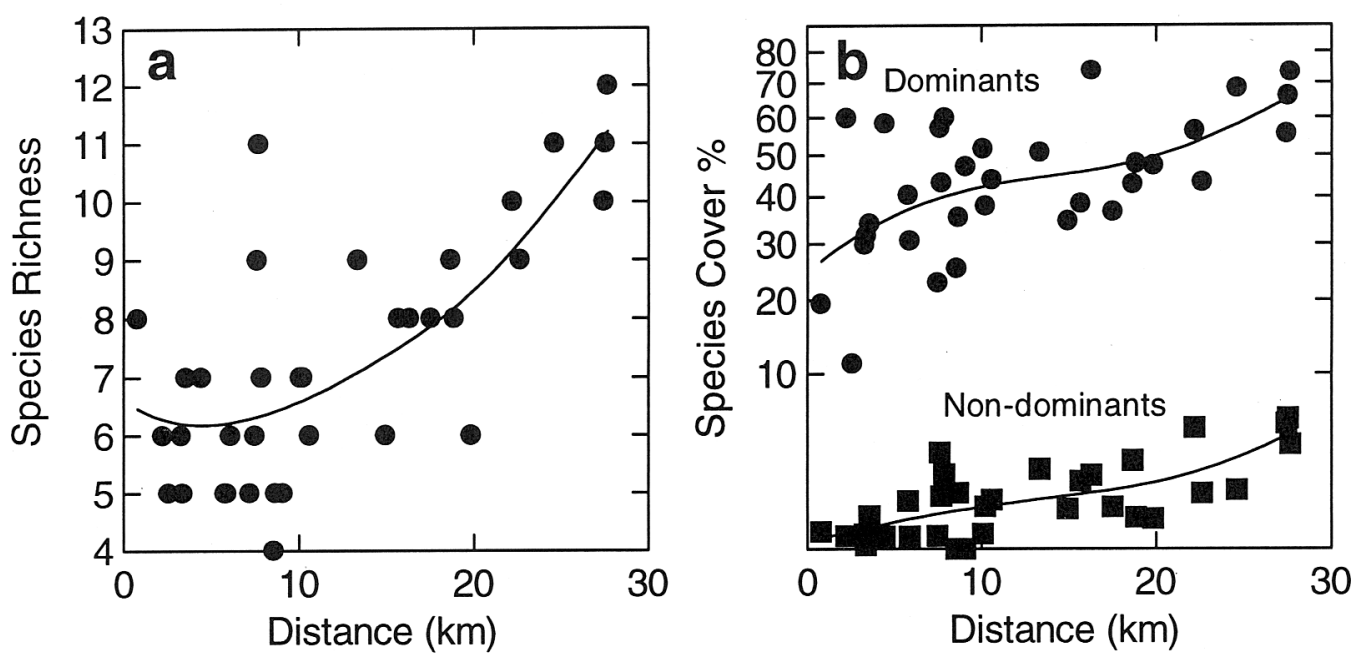

FIGURE 2. Lichen species richness (a) and total cover (b) in relation to distance from the pollution source. Line is a distanceweighted least squares regression, tension 1 . The species cover y-axis is transformed, power 0.5 .

air pollution reduces species richness, decreases total cover, alters species composition, and amplifies the presence of pollution-tolerant lichen species. Phaeophyscia orbicularis is a pollution-tolerant species; Xanthoria polycarpa (a close relative of X. hasseana) and Ochrolechia are moderately to significantly sensitive to $\mathrm{SO}_{2}$ pollution (van Dobben and ter Braak 1999).

Several factors may have influenced the results. Lichen species richness differs among host tree species (Muir and McCune 1988). This influence was minimized by our choice of only Balsam Poplar and Trembling Aspen. Exposed and isolated tree patches may have had lower lichen cover and richness in part because isolated trees are more exposed to air pollutants than are forest trees (Smith 1981). Microsite differences may have affected our findings at some sites. The choice of four mature trees with maximum lichen cover at each site should have minimized differences due to unsuitable substrates (such as smooth bark on rapidly growing trees).

As the pollution originates from several sources, including refineries, local vehicle emissions, and urban combustion, distance from a single point source is a simplification. Most of the sites were near roadways and were likely affected by vehicle emissions. Differences in traffic load may have contributed to the variability in the lichen communities. Strathcona County official weekday traffic counts during 1997 and 1998 for arterial roads in the vicinity of Refinery Row ranged from 21120 to 36130 vehicles per day. In contrast, traffic counts near the easternmost rural sites ranged from 82 to 1252 vehicles per day (mean $326, n=15$ ).

A combination of industrial, vehicular, and urban emissions results in lower air quality in the Refinery Row area. Winds distribute and disperse the pollutants in complex ways evident in Figure 3. Air quality monitoring in Fort Saskatchewan, about $20 \mathrm{~km}$ northnortheast of Refinery Row, found that sulphur dioxide levels rose significantly (by 21\%) when winds were from the south-southwest (Albert Health and Wellness 2003), a fact attributed to wind dispersal of pollutants from east Edmonton.

Air pollution is a serious health concern of millions of people worldwide and has been linked with higher rates of allergies and respiratory and cardiovascular diseases (Health Canada 2004*). Numerous epidemiological studies have demonstrated a link between ambient air pollution and adverse human health effects (Alberta Health and Wellness 2003). It can be difficult, however, to establish a causal relationship between exposure to a specific contaminant and a resultant health effect. Lack of a demonstrated causal link between a pollution source and human health does not mean that no link exists. Indeed, precautionary common sense should assume there may be a link until the required controlled studies are conducted. Sensitive bioindicators such as lichens can be used in the interim to inform public policy.

While air pollution effects upon the lichen communities are evident, levels of local monitored air quality parameters appear to be within Alberta government guidelines. This should perhaps not come as a surprise. Air quality guidelines are based in part upon science and in part upon what is feasible within the socioeconomic objectives of stakeholders (Long Fu, Alberta Environment, personal communication, 9 February 2006). Our results indicate that current air quality guidelines are inadequate for the protection of the lichen communities. 

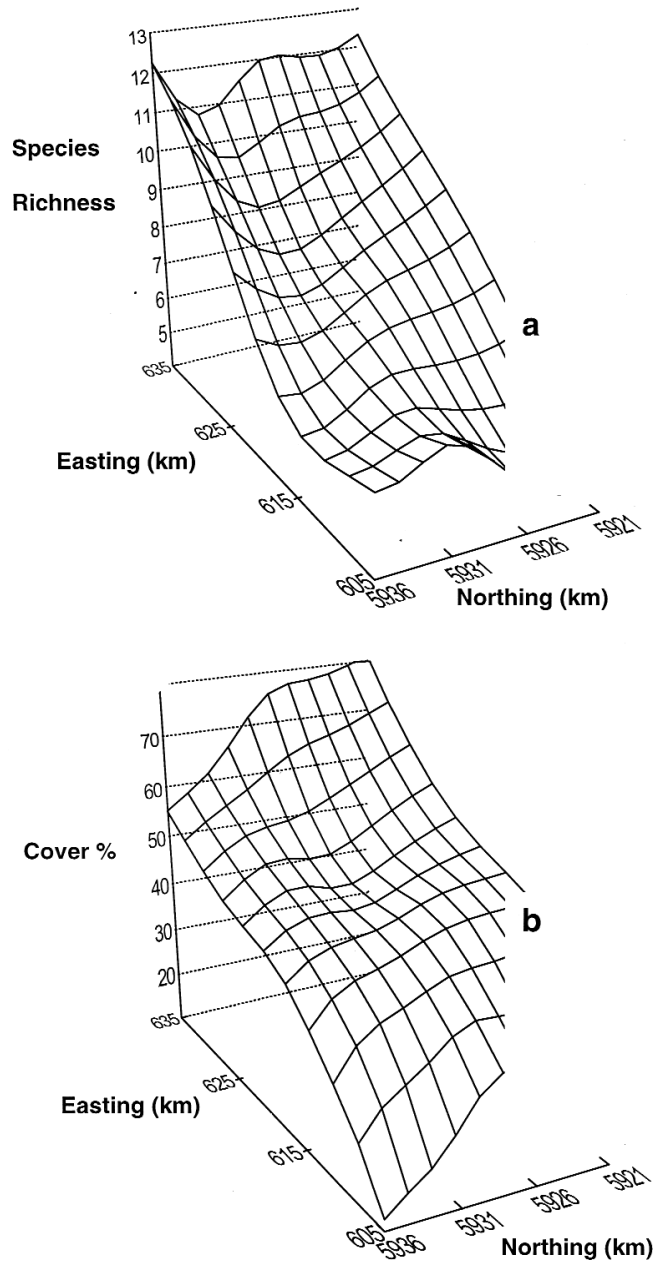

FIGURE 3. Lichen species richness (a) and total cover (b) in relation to location. The surface is a distance-weighted least squares regression, tension 1 . The view is from the northwest towards the southeast. Coordinates are in Alberta provincial 10TM projection.

Despite widespread public concern, independent, journal-published studies of the relationships between air pollution and human health downwind of the Strathcona Industrial Area have not been conducted to date. Alberta Health (1996) conducted a small, short-term study of respiratory disease rates in Strathcona County and Fort Saskatchewan. They were unable to detect above normal rates of mortality and hospital admissions but observed above normal rates of physician visits for asthma. As a large human population is needed for robust statistical analyses, the statistical power of that study was limited. Ozone, acid aerosols, nitrogen oxides, volatile organic compounds, and particulates may be responsible for adverse health effects at current levels of exposure (Alberta Health 1996).

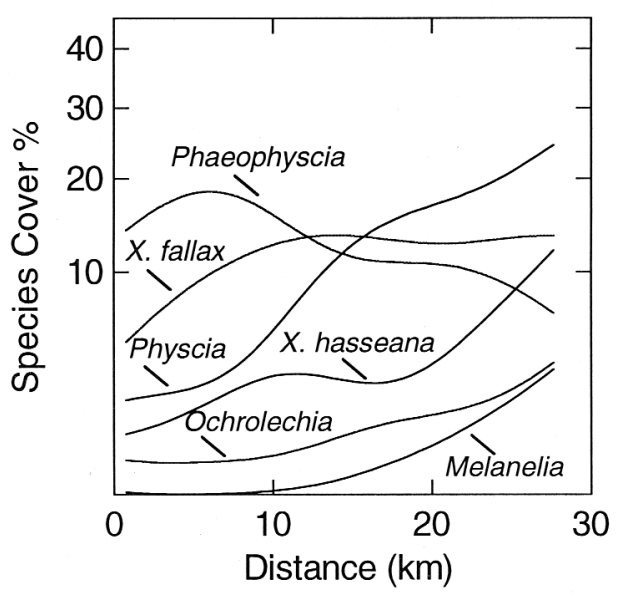

FIGURE 4. Lichen cover in relation to distance from the pollution source for the six dominant species. Line is a distance-weighted least squares regression, tension 1. The species cover $y$-axis is transformed, power 0.5 .

As regards particulate matter, epidemiologic studies have been conducted that reveal a coherence and consistency of effects across a range of health outcomes and independent studies in different settings (Dockery and Pope 1994). Weighted mean increases in daily mortality of $1.0 \%$ (all causes of death), $1.4 \%$ (for cardiovascular deaths), and $3.4 \%$ (for respiratory deaths) for each $10 \mu \mathrm{g} / \mathrm{m}^{3}$ increase in $\mathrm{PM}_{10}$ have been established (Dockery and Pope 1994). In Fort Saskatchewan, Alberta Health and Wellness (2003) observed a $95^{\text {th }}$ percentile $\mathrm{PM}_{2.5}$ outdoor concentration of $13.2 \mu \mathrm{g} / \mathrm{m}^{3}$, corresponding to a $\mathrm{PM}_{10}$ concentration of $\sim 23.3 \mu \mathrm{g} / \mathrm{m}^{3}$ (when the 2005 ratio of 0.568 for $\mathrm{PM}_{2.5}$ to $\mathrm{PM}_{10}$ in Alberta is applied). Such a concentration would be expected to cause an increased daily mortality of $2.3 \%$ for all causes of death, 3.3\% for cardiovascular deaths, and $7.9 \%$ for respiratory deaths (Dockery and Pope 1994).

Political decisions on regional air quality issues have to date supported business as usual. As Strathcona County Councillor Alan Dunn sees it (personal communication, 16 February 2006), "we politicians spend too much time sticking our heads in the sand." Councillor Glen Lawrence (personal communication, 16 February 2006) supports an improved air quality monitoring program. Both Councillors agree that protection of air quality and human health must begin to play a central role in future decisions regarding development.

Rates of death from asthma in Canada increased sharply from 1970 through the early 1980s and subsequently remained high through the 1980s (Wilkins and Mao 1993). In Alberta from 1980 to 1988, hospital admissions for asthma increased $35 \%$ for children younger than 15 years and increased 48\% for Albertans 15-34 years of age. Of all provinces in Canada, Alberta has the 
highest death rate for asthma in people younger than 35 years of age (Wilkins and Mao 1993).

As sentinels of air quality, the lichens are telling us that all is not well in the air east of Edmonton, Alberta.

Documents Cited (marked $*$ in text)

Alberta Environment. 1996. Air quality monitoring in Strathcona Industrial Area, Fall 1996. http://environment.gov.ab. ca/info/library/6380.pdf.

Alberta Environment. 1997. Air quality monitoring in Strathcona Industrial Area, Fall 1997. http://environment. gov.ab.ca/info/library/6384.pdf.

Case, J. W. 1981. Biomonitoring of air pollution in Alberta with lichens and mosses. Research Management Division, Alberta Environment. Edmonton, Alberta.

Enns, K. 2001. Assessment of the use of lichens as biomonitoring tools in the Athabasca Oil Sands Region. http:// www.wbea.org/component/option,com_docman/task,doc_ view/gid,45/.pdf.

Forest Health Highlights. 1994. Lichen assessments. http:// willow.ncfes.umn.edu/fhh-94/lichn_94.htm [no longer available on internet].

Health Canada. 2004. Health effects of air pollution. http:// www.hc-sc.gc.ca/ewh-semt/air/out-ext/effe/health_ effectseffets_sante_e.html.

McCarthy, D., and H. Vaughan. 2004. Arboreal lichens: preliminary indicators of Hamilton air quality. http://www. cleanair.hamilton.ca/conf/2004/pdf/presentations/arboreallichens-indicators-of-air-quality-dan-mccarthy.pdf.

Myrick, R. H., and K. M. Hunt. 1998. Air quality monitoring in Alberta: 1996 summary report. Alberta Environment. Edmonton, Alberta.

Pollution Watch. 2006. Pollution Watch Province Profile for 2005. http://www.pollutionwatch.org/province.do?chem Group $=$ all $\&$ year $=2005 \&$ pollutionType $=$ RETR_TOTAL COMBINED\&src=NPRI\&prov=AB. [year set to 2004 , 2003 , etc. for other years' data]

Simonson, S. 1996. Lichens and lichen-feeding moths (Arctiidae: Lithosiinae) as bioindicators of air pollution in the Rocky Mountain Front Range. http://www.colostate.edu/
Depts/Entomology/courses/en570/papers_1996/simon son.html.

USGS [U.S. Geological Survey]. 2005. NPLICHEN: a database of lichens in the U.S. National Parks. http://www.ies. wisc.edu/nplichen/.

\section{Literature Cited}

Alberta Health. 1996. Geographic and temporal variations of selected respiratory diseases in Strathcona County and Fort Saskatchewan. Alberta Health. Edmonton, Alberta.

Alberta Health and Wellness. 2003. Fort Saskatchewan and area community exposure and health effects assessment program. Final Report. Alberta Health and Wellness. Edmonton, Alberta.

Brodo, I. M., S. D. Sharnoff, and S. Sharnoff. 2001. Lichens of North America. Yale University Press. New Haven, Connecticut.

Dockery, D. W., and C. A. Pope III. 1994. Acute respiratory effects of particulate air pollution. Annual Review of Public Health 15: 107-132.

Muir, P. S., and B. McCune. 1988. Lichens, tree growth, and foliar symptoms of air pollution: are the stories consistent? Journal of Environmental Quality 17: 361-370.

Smith, W. H. 1981. Air Pollution and Forests. SpringerVerlag. New York, New York.

Stringer, P. W., and M. H. L. Stringer. 1974. Air pollution and the distribution of epiphytic lichens and bryophytes in Winnipeg, Manitoba. The Bryologist 77: 405-426.

Thormann, M. N. 2006. Lichens as indicators of forest health in Canada. The Forestry Chronicle 82: 335-343.

van Dobben, H. F., and C. J. F. ter Braak. 1999. Ranking of epiphytic lichen sensitivity to air pollution using survey data: a comparison of indicator scales. The Lichenologist: 31: 27-39.

Wilkins, K., and Y. Mao. 1993. Trends in rates of admission to hospital and death from asthma among children and young adults in Canada during the 1980s. Canadian Medical Association Journal 148: 185-190.

Received 22 February 2006

Accepted 11 April 2007 